109 - Das meistgebaute Jagdflugzeng der Welt, Entwicklung, Erprobung und Technik. Alle Varianten: von $B f(\mathrm{Me}) 109 \mathrm{~A}$ bis $109 \mathrm{E}$. Landshut 1997, ISBN 3-925505-32-6.

Suzuki, Hiroyuki: "Authenticity of Setting in the Cyclical Culture". Nara Conference on Authenticity in relation to the World Heritage Convention. Paris 1995, ISBN 82-519-1416-7.

Waidacher, Friedrich: Handbuch der Allgemeinen $\mathrm{Mu}$ seologie. Vienna 1993, ISBN 3-205-98445-5.

Vilkuna, Janne: Täytetyn tiikerin äärellä-museologia, mitä se on? Finnish Science Academy, Yearbook 2003, Special edition. Jyväskylä 2003, ISBN 951-796-331-9.

\section{INTERNET REFERENCES}

Lehmann, Hans Kr. 2000: http://www.famlehmann.com/katedral-Roskilde.htm. Printed on January 6, 2005.

Prescott, Kelly: Auto History Online, Ferdinand Porsche. http://www.autohistory.org/feature 6.html. Read on October 18, 2005.

*Hannu Valtonen is a retired Lt. Col from the Finnish Air Force and a retired Director of the Aviation Museum of Central Finland. He is the first Finnish PhD of Museology.

Email: hannu.valtonen@kolumbus.fi
Valtonen, Hannu: From Commonplace to Curiosity - The Museum Value of two Messerschmitt Bf 109 - Aircraft at the Central Finland Aviation Museum/TAVALLISESTA KURIOSITEETIKSI - Kahden Keski-Suomen Ilmailumuseon Messerschmitt Bf 109 lentokoneen museoarvo. Jyväskylä: University of Jyväskylä, 2006. Jyväskylä studies in Humanities. ISSN 1459-4323). ISBN 95139-2365-7. 104 pages.

Staff officer Hannu Valtonen's doctoral dissertation in museology "Tavallisesta kuriositeetiksi - Kahden Keski-Suomen ilmailumuseon Messerschmitt Bf 109-lentokoneen museoarvo" (From Commonplace to Curiosity - The Museum Value of two Messerschmitt Bf 109 Aircraft of the Aviation Museum of Central Finland ) is based on three previously published works on Messerschmitt aircraft by the author: 1) Lapin lentokonehylyt. Yli 20 vuotta pohjoista lentokonearkeologiaa (Aircraft Wrecks of Lapland - Over 20 Years of Northern Aircraft Archaeology,1993), 2) Luftwaffen pohjoinen sivusta. Saksan ilmavoimat Suomessa ja Pohjois-Norjassa 1941-1944 (The Northern Flank of the Luftwaffe - German Air Force in Finland and Northern Norway in 1941 1944, from 1997) and 3) Messerschmitt Bf 109 ja Saksan sotatalous (The Messerschmitt Bf 109 and the War Economy in Germany, 1999). The dissertation is the first doctoral thesis in museology to be submitted in Finland, which must naturally be taken into account when evaluating Valtonen's success in this venture and the scholarly significance of the study for museological research. The only comparisons are to be found in studies in ethnology and art history among other subjects, but there is no counterpart to Valtonen's work in material culture studies . 
110 Hannu Valtonen is one of the most experienced specialists in military aviation in Finland. After resigning from his officer's commission in the Finnish Air Force, Hannu Valtonen pursued a second career in the aviation museum field. He has been highly interested in war planes since his childhood and has written numerous books especially on German aircraft of the Second World War. This last-mentioned aspect at least partly explains the choice of topic of his dissertation.

The Messerschmitt Bf 109 has until now been the most numerously produced light fighter aircraft in the world. The total produced number of these planes lies between 36,000 and 37, 000. However, because of the German defeat at the end of the war the Messerschmitt Bf 109 soon became a rarity, and this is the case nowadays also in museums.

The Finnish Air Force was among the few air forces that used Messerschmitt Bf 109 fighters in the Second World War, to be precise in Finland in the so-called Continuation War of 1941-1944. The first of these aircraft were flown in Finland in the spring of 1943. Finland had a total of 164 of these planes - of two different types, the G-2 and the G-6. The Bf 109 remained in service in Finland also after the war, until early 1950s. The last flight in the Finnish Air Force with a Messerschmitt Bf 109 took place on 13 March 1954.

Only some 15 authentic Messerschmitt Bf 109 s have survived until the present in the world. Three of these are in Finland, which makes the study of this plane interesting both historically and museologically.

Hannu Valtonen addresses two research problems in his thesis. The first deals with the authenticity of the two Messerschmitt Bf 109s that are on display in the Aviation Museum of Central Finland. The second question tries to establish why the Messerschmitt Bf 109 was selected as the main type of light fighter aircraft in National Socialist Germany, how the Germans were able to keep the plane operational during the war and what influence it had on the German Luftwaffe and the Finnish Air Force. The dissertation consists of a summary and three previously written books (Aircraft Wrecks of Lapland - Over 20 Years of Northern Aircraft Archaeology, The Northern Flank of the Luftwaffe - The German Air Force in Finland and Northern Norway in 1941 - 1944 and The Messerschmitt Bf 109 and the War Economy in Germany, all however, written in Finnish), providing a considerable amount of information on these two planes in the Aviation Museum of Central Finland as well as historical details on the birth and lifespan of Messerschmitt Bf 109s as a whole.

From a historical point of view, the number of sources chosen by Valtonen for his dissertation is rather large and in addition many of them are primary sources from German military archives. This provides reliability for the work. Regardless of this, the author does not especially analyse his sources, although it is obvious that he is quite familiar with the wide range of sources on his subject. Why this is not done is not made clear in the dissertation. Furthermore, Valtonen does not mention the details of his research methods when collecting material and writing the above-mentioned books that provide background information in his study. In a way this is strange, because the author is not a beginner in historical studies. It would not have been much trouble to explain in a few words the character of the different source groups, their value for different parts of the thesis and their possible failings. This would have provided even more re- 
liability for the books attached to this dissertation, which in themselves are quite thoroughly written.

The reader expects also some descriptions of previous research if such exists, and if not the question still remains. It is known that there are no studies - excluding articles - seeking to establish the origins and authenticity of the Messerschmitts still in Finland. There are, however, works of research on the production of Messerschmitt Bf 109s, their existence and role in the German Air Force as well as material on the planes that came to Finland and remained there. A brief analysis of the above mentioned would have shown the reader why this study was worth conducting and where this work can be situated among previous research in this subject on a broader wider scale. Although the main emphasis in the dissertation is on the question of whether or not the two Messerschmitts in the Aviation Museum of Central Finland are authentic and original, Valtonen's work also sheds light also on the manufacturing process of the Messerschmitt Bf 109 and the attached books provide found several well-argued explanations of why and how the aeroplane was kept in production until the defeat of Germany in 1945. Valtonen also describes the activities of the German 5th Air Command in Lapland. This gives the reader a good framework for understanding the conditions under which the other subject of the dissertation, the Messerschmitt Bf 109 F4, NE+ML, was destroyed. Therefore, although the previously written books contain a great deal of secondary information, they are nonetheless necessary in backing up the primary question of the thesis by giving background information on issues that are needed to evaluate the authenticity of the two planes, i.e. the subjects of the thesis, the MT-507 used by the Finnish Air Force and the NE+ML used by the German 5th Air Command.

The Messerschmitt Bf 109 had an extraordinary long lifespan. It would have been interesting to compare this case with some other aircraft, for example its British contemporary the Hawker Hurricane during the Second World War. The author did not do so, and it was not even his purpose. Nevertheless, the Germans were able to modify the plane so that it was still in operational use up to the end of the war. In Finland, Messerschmitt Bf 109s plated in a remarkable role, especially in the summer of 1944 when the country fought for its existence. During two months of heavy fighting the Finns were able to halt the Red Army both in the Karelian Isthmus and in East Karelia. The Air Force was in central role by giving air cover and bombing Soviet troop concentrations on the ground. On the Finnish front, the Messerschmitt 109s were still very usable. There were no planes superior to them in dogfights, not even in the summer of 1944 , which can at least partly be explained because of the experienced and well-trained Finnish pilots. The results were amazing; over 650 Soviet aircraft were shot down with less than 50 Messerschmitt 109 in daily operational use between March 1943 and the end of August 1944. A large proportion of these air victories were gained in the summer 1944.

From the perspective of museology, the main issues of Hannu Valtonen's study are the developments that led to the Messerschmitt fighters in the Aviation Museum of Central Finland becoming museum objects and their genuineness and authenticity. There are problems of some degree in Valtonen's use of concepts, which is particularly evident when he defines concepts related to the philosophy of history. It would have been important, for ex- 
112 ample, to transfer the philosophical meaning of the idea of chance to museological studies. Valtonen's first work Lapin lentokoneenhylyt. Yli 20 vuotta pohjoista lentokonearkeologiaa (Aircraft Wrecks of Lapland - Over 20 Years of Northern Aircraft Archaeology ) is the most valuable one with regard to museological research. It cannot be described as a study as such but rather as documentation of the author's surveys in Lapland, a travel account or memoirs based on the author's own notes and recollections. Its documentation section can be assigned the role of a primary source and the personal recollections that of a secondary source, which should naturally be subjected to source criticism.

Here, as in museological research in general and artefact studies in particular, documentation along with the object itself provides the fundamental source material. As noted above, the attached work Lapin lentokoneenhylyt. Yli 20 vuotta pohjoista lentokonearkeologiaa (Aircraft Wrecks of Lapland - Over 20 Years of Northern Aircraft Archaeology) cannot be evaluated as research in the same sense as the other appended works. The documentation of wrecks concerns over 100 aircraft wrecks from the Second World War in Lapland. The use of documentation in the dissertation, however, is limited to only one object, the NE+ML in the collections of the Aviation Museum of Central Finland, although the documented aircraft wrecks could have provided at least some degree of comparative material for the museum objects and memorial plane considered in the study.

The appended works are problematic with regard to method. Valtonen does not focus particular attention on the methods of the appended works. Although matters related to method, with the exception of evaluating ear- lier studies and source criticism, are given little attention in military historical research, it should not be taken as a matter of course that nothing is said about the applied method and the working process. On the contrary, the method that is applied may provide added value for the work in question and especially for its further use.

With regard to museology, evaluating the methodological approach is difficult owing to the related issues of definition in this field. The surveying and documentation of the aircraft wrecks were largely conducted with methods followed by archaeological methods, although documentation of the latter standard, the pin-pointing of remains or the drawing plans and maps were not undertaken because of well-founded reasons. In terms of documentation, a Stone Age grave is no doubt completely different to an aircraft wreck. Lapin lentokoneenhylyt. Yli 20 vuotta pohjoista lentokonearkeologiaa (Aircraft Wrecks of Lapland - Over 20 Years of Northern Aircraft Archaeology) is also an arguable choice as the title of a published work.

Valtonen does not place his work on aircraft archaeology within the scholarly field of archaeology, and notes that aircraft archaeology does not necessarily have anything to do with archaeological research in general. According to its definition, archaeology is a discipline that studies the material traces of man that have been deposited in the ground, such as buildings, structures, graves and artefacts. As a discipline, archaeology does not place any chronological limits to its objects of study. They can just as well be prehistoric or from Second World War. Archaeological remains can also be partly above ground, such as a burial cairn, or under water. In comparing the study and documentation of different types of 
objects we can note that it is insignificant whether the object in question is a burial cairn, shipwreck or aircraft wreck. The research and documentation method should be archaeological in order to record sufficient information. On the grounds of the above, aircraft archaeology can be placed within archaeological research.

From the perspective of the disciplines recognized by the museum field, Valtonen can be said to have succeeded quite well with regard to the study and documentation of artefacts. The main problems are evident in his command of the methods of historical research and source criticism. From the museological perspective, Valtonen succeeds particularly well in applying Peter van Mensch's theory of the life span of an object to the Messerschmitt fighters of his study and in defining their museum value. I find it particularly commendable that the author has succeeded in establishing the origin of all the aircraft considered by him, from their date of manufacture to their inclusion in museum collections. This was done primarily with the methods of historical research, but the information thus obtained was excellently applied in establishing the life span of the objects concerned. The object acquired the meaning of a source, which aroused more and more questions for the author.

Valtonen uses and discuses museological concepts mostly without reproach. In some cases, the evaluation of concepts and their differences could have been taken further. Answers could have been provided for example to questions such as the difference between a museum aircraft and a memorial aircraft. Also the concepts of conservation, preventive conservation, restoration and renovation could have been explained better and their meaning and connection with the museum pieces 113 could have evaluated. In a sense, the concepts are question for which one expects answers that are not actually given. The author should also have evaluated more closely whether restoration raises the value of an object or whether this value peaks when the object is taken into a museum collection. In some connections, the author also applies value statements alien to historical researchers.

With regard to museological research, it is necessary to consider the way in which Valtonen's relates to this field. Museology is traditionally divided into 1) meta-museology addressing the general nature and grounds of museology, the epistemology of museology and what this field is really about, 2) historical museology describing and explaining the circumstances and conditions bound to time and place through which the museum aspect emerges, 3) theoretical museology as a basic discipline of the field considering issues of information and value criticism, and 4) applied museology. Valtonen's study can be said to fall into areas of historical and, in particular, theoretical museology, underlining a distinct aim at solving issues of information and value criticism.

Hannu Valtonen's Valtonen is a remarkable work in two ways. It is the first dissertation made in the subject of museology in Finland. Secondly, from the historical point of view the study brings again into daylight the almost forgotten role of the Messerschmitt Bf 109s as the most numerously produced fighter aircraft in the world. Despite this, the airplane is now a real rarity, with only some 15 remaining. The Finns are lucky, owning three of them, all genuine and two almost ready to take off. In parts of his dissertation Hannu Valtonen achieves an exceptionally thorough documen- 
114 tation of the life span of objects of study. Taking Peter van Mensch's lifespan theory as his background he has succeeded in provided the studied museum objects with an astounding context including details such as the nationality of the concentration-camp prisoners that participated in the manufacture of the aircraft.

Pasi Kesseli is a Lieutenant Colonel, Ph.D. and Professor at the National Depence College, Finland.

E-mail: pasi.kesseli@mil.fi

Juhani Kostet is Ph.D., Docent of Museology (Turku University) and Director of Turku Provincial Museum, Finland.

E-mail: juhani.kostet@turku.fi

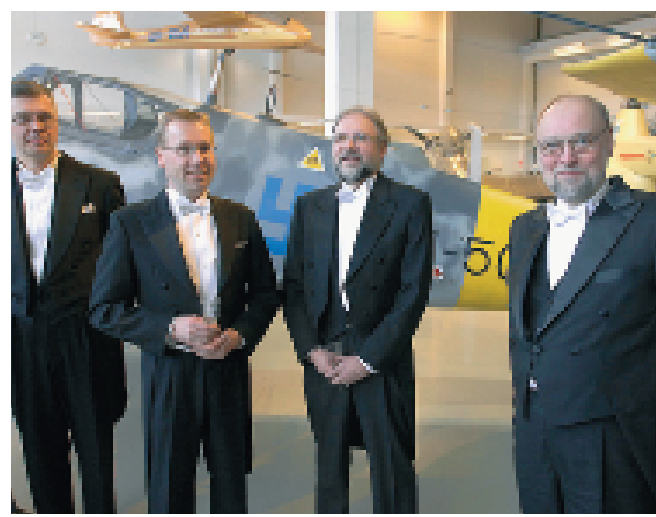

Disputationens "stjärnor" i Mellersta Finlands Flygmuseum efter disputationen, 24. marts 2006: I backgrunden (den andra) Messerscmitt Bf 109 och framför frän vänster kostod Janne Vilkuna, opponenterna överstelöjtnant och professor vid Militärhögskolan Pasi Kesseli och docent $i$ museologi vid Abo universitet och museichef vid Ảbo museer Juhani Kostet och respondenten överstelöjtnant och före detta museichef vid Mellersta Finlands Flygmuseum. Hannu Valtonen. Foto Leo Skogström. 